\title{
Penyelesaian Sengketa Hak Ulayat pada Kawasan Hutan
}

\author{
Adonia Ivone Laturette \\ Fakultas Hukum Universitas Pattimura, Ambon, Indonesia \\ E-mail: laturettedony@yahoo.com
}

Dikirim: 07/02/2021

Info Artikel

Keywords:

Dispute Resolution;

Customary Rights,

Peacefully.

Kata Kunci:

Penyelesaian

Sangketa;

Hak

Ulayat; Secara Damai.
Direvisi: 25/03/2021

Dipublikasi: $13 / 4 / 202$

\section{Abstract}

Customary law communities are one of the legal subjects of the state that are recognized in statutory regulations. Customary law communities have a multidimensional relationship with customary rights, not just an economic resource, but an integral part of the overall life of the customary law community. This research aims to study and analyze the settlement of disputes by indigenous peoples over land exploitation which is customary rights in the Forest Zone. The research method used in this research is normative juridical research, namely the method of doctrinal law research by examining and examining the provisions of the applicable laws and regulations as a basis for later analyzing the problems being studied. Based on the results of the research that the importance of the role of land in human life, land becomes an object that is prone to disputes or disputes between humans, this happens because human needs for land are increasing, land can cause disturbances and involve the community at large, so it is demanded to handle it appropriately. The parties involved and authorized to deal with the issue of customary rights in the forest area of indigenous peoples, resolve it in various ways. The method of dispute resolution that has been taken so far is through court (litigation). Over time, dispute resolution through deliberation is increasingly being carried out. Land disputes, which are more related to issues of interest or interest of the parties, are relatively easier to resolve through deliberation as long as both parties are open to each other and want the best solution for all parties.

\section{Abstrak}

Masyarakat hukum adat merupakan salah satu subjek hukum negara yang diakui dalam peraturan perundang-undangan. Masyarakat hukum adat memiliki hubungan multidimensi dengan hak ulayat, bukan sekadar sumber ekonomi, tetapi merupakan bagian tidak terpisahkan dari keseluruhan kehidupan masyarakat hukum adat. Penelitian ini bertujuan untuk mengkaji dan menganalisis penyelesaian sengketa masyarakat hukum adat atas eksploitasi tanah yang merupakan hak ulayat pada Kawasan Hutan. Metode penelitian yang digunakan dalam penelitian ini adalah penelitian yuridis normatif, yakni metode penelitian Hukum doktrinal dengan mengkaji dan menelaah ketentuan peraturan perundang-undangan yang berlaku sebagai dasar untuk kemudian menganalisis permasalahan yang dikaji. Berdasarkan hasil penelitian bahwa pentingnya peran tanah dalam kehidupan manusia, tanah menjadi objek yang rawan terhadap perselisihan atau sengketa antar manusia, hal ini terjadi karena kebutuhan manusia akan tanah semakin meningkat, tanah dapat menimbulkan gangguan-gangguan dan melibatkan 
DOI:

10.47268/sasi.v27i1.504

$\overline{\text { masyarakat banyak maka dituntut penangan secara tepat. Para pihak yang }}$ terkait dan berwenang menangani permasalahan hak ulayat pada kawasan hutan masyarakat adat, menyelesaikan dengan berbagai cara. Cara penyelesaian sengketa yang telah ditempuh selama ini adalah melalui pengadilan (litigasi). Seiring dengan perjalanan waktu, penyelesaian sengketa melalui cara musyawarah semakin bayak di lakukan. Sengketa pertanahan yang lebih banyak berkaitan dengan masalah kepentingan atau interes para pihak, relatif lebih mudah untuk diselesaikan melalui cara musyawarah sepanjang kedua belah pihak saling terbuka dan menginginkan jalan keluar yang terbaik bagi semua pihak.

\section{A. PENDAHULUAN}

Tanah bagi kehidupan manusia mempunyai kedudukan yang sangat penting. Hal ini disebabkan hampir seluruh aspek kehidupannya terutama bagi bangsa Indonesia tidak dapat terlepas dari keberadaan tanah yang sesungguhnya tidak hanya dapat ditinjau dari aspek ekonomi saja, melainkan meliputi segala kehidupan dan penghidupannya. Tanah mempunyai multiple value, maka sebutan tanah air dan tumpah darah dipergunakan oleh bangsa Indonesia untuk menyebutkan wilayah negara dengan menggambarkan wilayah yang didominasi tanah, air, dan tanah yang berdaulat. ${ }^{1}$ Selain itu tanah seabagi salah satu komponen ekosistem yang sangat strategis untuk kelangsungan hidup umat manusia, serta pula sebagai faktor utama dalam tiap aktivitas pembangunan, ${ }^{2}$ pengadaan tanah bagi pembangunan untuk kepentingan umum merupakan problem klasik yang senantiasa memunculkan sengketa dimasyarakat ${ }^{3}$. Pasal 1 butir 6 Perpres Nomor 65 Tahun 2006 tentang Pengadaan Tanah Bagi Pelaksanaan Pembangunan Untuk Kepentingan Umum menyatakan bahwa Pelepasan atau penyerahan hak atas tanah adalah kegiatan melepaskan hubungan hukum antara pemegang hak atas tanah dengan tanah yang dikuasainya dengan memberikan ganti rugi atas dasar musyawarah. ${ }^{4}$

Arti penting tanah bagi manusia sebagai individu maupun negara sebagai organisasi masyarakat yang tertinggi, secara konstitusi diatur dalam Pasal 33 ayat (3) Undang-Undang Dasar 1945 yang menyatakan bahwa: "Bumi, air dan kekayaan alam yang terkandung di dalamnya dikuasai oleh negara dan digunakan sebesar-besarnya bagi kemakmuran rakyat". Sebagai tindak lanjut dari Pasal 33 ayat (3) Undang-Undang Dasar 1945 yang berkaitan dengan bumi atau tanah, maka dikeluarkanlah Undang-Undang Nomor 5 Tahun 1960 tentang Peraturan Pokok Dasar Agraria yang selanjutnya lebih dikenal dengan sebutan UUPA. Tujuan pokok dari UUPA adalah: ${ }^{5}$

1) Meletakkan dasar-dasar bagi penyusunan hukum agrarian nasional, yang merupakan alat untuk membawa kemakmuran, kebahagiaan dan keadilan bagi Negara dan rakyat, terutama rakyat dalam rangka masyarakat adil dan makmur.

2) Meletakkan dasar-dasar untuk mengadakan kesatuan dan kesederhanaan dalam hukum pertanahan.

1 Laturette, A.I. (2016). Penyelesaian Sengketa Hak Atas Tanah Masyarakat Hukum Adat. SASI, 22(2), 5266. DOI: https://doi.org/10.47268/sasi.v22i2.168, h. 52.

${ }^{2}$ Hetharie, Y. (2019). Perjanjian Nominee sebagai Sarana Penguasaan Hak Milik atas Tanah oleh Warga Negara Asing (WNA) Menurut Kitab Undang-Undang Hukum Perdata.SASI, 25(1), 27-36. DOI: https://doi.org/10.47268/sasi.v25i1.147, h. 2t.

3 Kotalewala, F., Laturette, A.I., \& Uktolseja, N. (2020). Penyelesaian Sengketa dalam Pengadaan Tanah Bagi Pembangunan Jalan untuk Kepentingan Umum. SASI, $26 \quad$ (3), 415-433. https://doi.org/10.47268/sasi.v26i3.397, h. 415.

${ }^{4}$ Hallauw, D.K., Matuankotta, J.K., \& Uktolseja, N. (2020). Analisis Hukum Surat Pelepasan Hak Atas Tanah Adat (Dati) Di Kota Ambon. SASI, 26 (1), 111-118. https://doi.org/10.47268/sasi.v26i1.256, h. 113.

5 Laturette, A.I. (2016). Op. Cit. h. 52.

$$
103 \text { | S A S I Vol. } 27 \text { No.1, Januari- Maret } 2021
$$


3) Meletakkan dasar-dasar untuk memberikan kepastian hukum mengenai hak-hak atas tanah bagi rakyat seluruhnya.

Kehadiran UUPA didesain untuk mengakhiri pluralitas pranata hukum yang mengatur bidang pertanahan dan ingin menciptakan satu tata hukum tanah nasional, dengan menjadikan hukum adat sebagai dasarnya, sekalipun UUPA menggunakan istilah agraria, namun substansi pengaturannya lebih berhubungan dengan hukum tanah sebagai bidang hukum utama dari hukum agrarian. ${ }^{6}$

Oleh karena itu untuk dapat mencapai kemakmuran dan kesejahteraan rakyat, maka dalam memanfaatkan dan menggunakan tanah yang merupakan bagian dari sumber daya alam harus dilaksanakan secara bijaksana dan dalam pengelolaannya diserahkan kepada negara. Undang-Undang Nomor 5 Tahun 1960 yang lebih dikenal dengan sebutan UUPA secara ideologis mempunyai hubungan yang sangat erat dengan kaum petani Indonesia. Hal ini dikarenakan sejak berlakunya UUPA, secara yuridis formal ada keinginan yang sangat kuat untuk memfungsikan hukum agraria nasional sebagai "alat" untuk membawa kemakmuran, kebahagiaan dan keadilan bagi negara dan masyarakat tani dalam rangka masyarakat adil dan makmur, karena dalam kehidupan masyarakat khususnya di daerah pedesaan, tanah merupakan salah satu faktor produksi yang sangat penting, karena tanah merupakan salah satu sumber hidup dan kehidupan mereka, di samping itu tanah-tanah adat sering dihubungkan dengan nilai kosmis-magis-religius. Hubungan ini bukan saja antara individu dengan tanah, tetapi juga antar sekelompok anggota masyarakat suatu persekutuan hukum adat di dalam hubungan dengan hak ulayat. Bagi negara Indonesia, sebagai negara yang agraris keberadaan tanah memiliki fungsi yang sangat penting bagi kemakmuran dan kesejahteraan rakyatnya.

Di negara seperti Indonesia fungsi tanah kian meningkat dan mempunyai nilai ekonomis yang sangat tinggi. Dari sekian banyak bidang yang menyangkut tanah, bidang ekonomi nampak mendominasi aktivitas manusia atas tanah. Hal ini berkaitan dengan kelangsungan hidup manusia, dimana pertumbuhan penduduk serta pertumbuhan ekonomi yang melaju pesat. Sering kali karena pentingnya peran tanah dalam kehidupan manusia, tanah menjadi objek yang rawan terhadap perselisihan atau sengketa antar manusia, hal ini terjadi karena kebutuhan manusia akan tanah semakin meningkat, namun persediaan tanah relatif tetap.

Negara dalam hal ini melakukan upaya dengan melakukan perlindungan terhadap masyarakat hukum adat di Indonesia dengan tetap menjaga kemanfaatan, kearifan lokal, sosial dan budaya dalam penggunaan hak ulayat. ${ }^{7}$ Pengakuan keberadaan hak ulayat diakui oleh undang-undang Nomor 5 Tahun 1960 tentang pengaturan Dasar Pokok-Pokok Agraria sepanjang eksistensinya masih ada, sebagaimana yang dapat disimpulkan dari Pasal 3 Jo Pasal 58 UUPA yang mengakui masih berlakunya hak ulayat maupun hak-hak lainnya yang tidak bertentangan dan sepanjang belum diatur secara khusus. Pengakuan hukum adat sebagaimana disebutkan dalam UUPA, pada hakikatnya tidak jelas pengaturannya, ketidakjelasan tersebut menunjukkan bahwa para pembentuk UUPA sebenarnya bimbang dan ragu terutama tentang hukum adat mana yang diberlakukan. Disamping itu juga penjajahan dengan sistem positivisme hukum turut mewarnai sistem hukum Indonesia yang berpengaruh kuat pada saat itu ${ }^{8}$. Namundalam Keputusan Menteri Negara Agraria/ Kepala BPN No. 5 Tahun 1999, Pasal 1 ayat (1) secara tegas mengatur bahwa Hak Ulayat adalah wewenang yang menurut hukum adat dipunyai oleh masyarakat hukum adat tertentu atas wilayah tertentu yang merupakan

6 Shidarta. (2010). Peragaan Pola Penalaran Hukum dalam Kajian Putusan Kasus Tanah Adat". Jurnal Yudisial, 3 (3), 207-219. http://dx.doi.org/10.29123/jy.v3i3.208, h. 218

7 Achmad, I. A., Risdiwanto, G., \& Rezandy, J. G. (2020). Kewenangan Hak Menguasai Negara Atas Hak Ulayat Pada Kawasan Hutan Lindung. Soumatera Law Review, 3 (1), 81-92. http://doi.org/10.22216/soumlaw.v3i1.5102, h. 81.

8 Saija, R., Letsoin, F.X., Akyuwen, R.J., \& Radjawane, P. (2020). Status Kepemilikan Hak Atas Tanah Adat Marga dalam Kebijakan Penataan Aset Reforma Agraria Di Kabupaten Maluku Tenggara. SASI, 26 (1), 99 110. https://doi.org/10.47268/sasi.v26i1.246, h. 100.

$$
104 \text { | S A S I Vol. } 27 \text { No.1, Januari-Maret } 2021
$$


lingkungan hidup para warganya untuk mengambil manfaat dari sumber daya alam, termasuk tanah dalam wilayah tersebut bagi kelangsungan hidup dan kehidupannya, yang timbul dari hubungan secara lahiriah dan batiniah turun temurun dan tidak terputus antara masyarakat hukum adat tersebut dengan wilayah yang bersangkutan. Ketentuan di atas menunjukan bahwa Hak Ulayat harus benar-benar masih ada dan tidak diberikan peluang untuk menimbulkan kembali hak-hak tersebut, jika secara faktual dalam masyarakat sudah tidak ada lagi. Namun ketentuan di atas tidak memberikan syarat ang menunjukan masih ada atau tidaknya Hak Ulayat suatu masyarakat hukum adat. Keberadaan Hak Ulayat harus diikuti dengan hubungan antara tanah dan masyarakat. Dengan demikian selama tanah ulayat tersebut ada, haruslah dimanfaatkan oleh warga masyarakat guna meningkatkan kesejahteraan. ${ }^{9}$

Selain itu tersirat pengakuan atas hak ulayat yang terdapat dalam UUD Tahun 1945 Pasal 18B ayat(2). Sedangkan pengakuan keberadaan hak ulayat dalam Undang-Undang Kehutanan tidak secara detail mengenai pengaturan keberadaan hak ulayat. Melainkan hanya mengatur mengenai hutan adat dan masyarakat hukum adat, meskipun rumusan hutan adat adalah hutan negara yang berada dalam wilayah masyarakat, meskipun Undang-Undang kehutanan merupakan Undang-undang yang bersifat khusus sedangkan UUPA bersifat umum, banyak pemanfaatan hutan yang dilakukan dengan sengaja tanpa ijin, yang mana didalamnya terdapat hutan adat atau hutan ulayat yang merupakan perwujudan dari hak ulayat masyarakat hukum adat setempat namun sering kali terjadi pelanggaran terhadap hak adat tersebut yang terjadi karena adanya peraturan yang saling bertentangan, belum adanya pengaturan tentang kepemilikan kolektif atas tanah sehingga menyebabkan ketidakjelasan prosedur pengakuan hak kolektif masyarakat adat atas tanah, untuk itu diperlukan cara penyelesaian sangketa tanah melalui musyawarah atau penyelesaian lewat jalur non litigai agar dapat mencegah konflik yang berkepanjangan.

Sengketa tanah dalam masyaratkat setiap tahun semakin meningkat dan terjadi hampir di seluruh daerah di Indonesia baik di perkotaan maupun di pedesaan termasuk salah satunya di Maluku. Kasus pertanahan yang sering terjadi bila dilihat dari konflik kepentingan para pihak dalam sengketa pertanahan antara lain: ${ }^{10}$

1) Rakyat berhadapan dengan birokrasi

2) Rakyat berhadapan dengan perusahaan negara

3) Rakyat berhadapan dengan perusahaan swasta

4) Konflik antara rakyat Hampir di setiap daerah yang terdapat sengketa tanah ulayat.

\section{B. METODE PENELITIAN}

Metode penelitian yang digunakan dalam penelitian ini adalah penelitian yuridis normatif $^{11}$, yakni metode penelitian Hukum doctrinal dengan mengkaji dan menelaah ketentuan peraturan perundang-undangan yang berlaku sebagai dasar untuk kemudian menganalisis permasalahan yang dikaji. Penelitian ini bersifat deskriptif analitis dengan menggunakan bahan hukum primer dan bahan hukum sekunder melalui studi dokumen dan literatur terkait. Analisis yang digunakan dalam penelitian ini adalah analisis kualitatif guna menjawab permasalah yang dikaji.

\section{PEMBAHASAN}

\section{Sengketa hak ulayat pada masyarakat}

9 Lakburlawal, M. A. (2016). Akses Keadilan bagi Masyarakat Adat dalam Penyelesaian Sengketa Tanah Ulayat yang Diberikan Hak Guna Usaha. ADHAPER: Jurnal Hukum Acara Perdata, 2 (1), 59-75. http://doi.org/10.36913/jhaper.v2i1.24, h. 64.

10 Sumardjono, Maria S.W. (2005). Kebijakan Pertanahan, Antara Regulasi dan Implementasi, Jakarta : Kompas, h. 182.

${ }^{11}$ Irianto, Sulistyowati. (2009). Praktik Hukum: Perspektif Sosiolegal, Jakarta: Yayasan Obor, h. 308 
Sengketa ini berkaitan dengan hak-hak keperdataan, baik oleh subyek hak maupun oleh pihak-pihak lain yang berkepentingan terhadap obyek haknya (tanah). Adapun yang menjadi pokok permasalahan berkaitan dengan kepastian hak atas tanahnya. ${ }^{12}$ Sehagairnana diketahui bahwa proses penetapan suatu hal atas tanah termasuk penerbitan surat keputusan dan sertifikatnya, sangat tergantung pada data fisik dan data yuridis yang disampaikan pihak yang menerima hak kepada Badan Pertanahan Nasional. Apabila data yang disampaikan mengandung kelernahan-kelemahan, maka demikian pula kualitas kepastian hukurn mengenai hak atas tanah akan mengandung kelemahan yang pada suatu saat dapat dibatalkan apabila terbukti cacat administrasi maupun cacat hukum.

Memperoleh suatu hak atas tanah serta mendapatkan sertifikat atas tanah sebagai bukti kepemilikan dapat ditempuh melalui dua cara, yaitu konversi bekas hak lama dan tanah bekas hak milik adat serta permohonan hak $^{13}$. Sistern publikasi pendaftaran tanah Indonesia yang menganut stelsel negatif yang bertendes positif, tidak memungkinkan untuk memberikan jaminan kepastian hukum secara mutlak. Jaminan kepastian hukum dirnaksud hanya ada apabila data fisik dan data yuridis yang tercanturn di dalam buku tanah, sertifikat dan dafiardaftar isian lainnya, sesuai dengan kenyataan di lapangan. Oleh karena itu, suatu hak atas tanah masih terbuka untuk dibatalkan, baik berdasarkan putusan badan peradilan maupun berdasarkan kenyataan yang sebenamya dilapangan, dengan dernikian maka keabsahan atas hak sebagai dasar penetapan suatu hak sebagai dasar penetapan suatu hak tanah sangat penting dalam rangka memberikan jaminan kepastian hukurn.

Meskipun menganut stelsel negative, tidak berarti dalam memproses suatu hak, Badan Pcrtanahan Nasional bersikap positif, dalam rangka pelaksanaan asas-asas urnum pernerintahan yang baik, proses penerbitan hak selalu dilakukan dengan standar ketelitian yang dapat dipertanggungawabkan, yaitu dengan jalan dilakukan penelitian riwayat tanah, penetapan batas secara contracditore, delimitatie, diumumkan serta dibukannya kesempatan bagi pihak-pihak yang berkepentingan untuk menyampaikan keberatan. ${ }^{14}$

Penggunaan tanah ulayat oleh para investor, seringkali menimbulkan sengketa. Hal ini disebabkan karena penggunaannya tidak sesuai dengan yang seharusnya. Menurut hukum pertanahan di Indonesia, penggunaan lahan oleh para investor harus berhadapan langsung dengan pemilik tanah atau masyarakat adat sebagai pemilik hak ulayat dengan melaksanakan perjanjian. Pada kenyataannya, para investor justru langsung mendapatkan tanah tersebut melalui Pemerintah. Akibatnya masyarakat sebagai pemilik mengajukan protes atas kegiatan investor di atas tanah mereka yang kemudian hal ini memicu timbulnya sengketa tanah ulayat. ${ }^{15}$

Fenomena sengketa tanah yang muncul, baik sengketa antara pemerintah dengan masyarakat, masyarakat dengan investor, pemerintah dengan pemerintah maupun masyarakat itu sendiri semakin intensif. Sebagian besar muncul sebagai akibat pembebasan tanah untuk kepentingan pembangunan infrastruktur, industri, perumahan, paiwisata maupun perkebunan skala besar.

Sengketa tanah sebagian besar terjadi antara masyarakat adat yang mempertahankan hak adat atas tanah dengan pemilik modal besar yang mendapatkan konsesi pengusahaan hutan, pertambangan, termasuk pertambangan minyak dan gas bumi, dan pengembangan agribisnis dengan pola PIR (Perkebunan Inti Rakyat). Gejala re-ciaming tanah oleh masyarakat terhadap unit dan asset-aset produktif yang telah dibangun diatasnya, rata-rata telah terjadi di seluruh

\footnotetext{
${ }^{12}$ Ibid, h. 81 .

13 Riardo, Rahmat. (2019). Konversi Hak Atas Tanah Ulayat Kaum Menjadi Hak Milik Melalui Program Pendaftaran Tanah Sistimatis Lengkap di Kota Solok. Soumatera Law Review, 2 (2), $193-206$. http://doi.org/10.22216/soumlaw.v2i2.3556, h. 193.

${ }^{14}$ Ibid, h, 81.

15 Warman, Kurnia. \& Syofiarti. (2012). Pola Penyelesaian Sengketa Tanah Ulayat Di Sumatera Barat (Sengketa antara Masyarakat vs Pemerintah). Masalah-Masalah Hukum, $41 \quad$ (3), 407-415. https://ejournal.undip.ac.id/index.php/mmh/article/view/5771, h. 407.$$
106 \text { | S A S I Vol. } 27 \text { No.1, Januari- Maret } 2021
$$ 
wilayah Indonesia. ${ }^{16}$ Masyarakat adat dapat membuktikan bahwa ia mempunyai alas hak atas tanah yang disengketakan. ${ }^{17}$

Pengertian sengketa menurut Peraturan Menteri Negara Agraria/ Kepala Badan pertanahan Nasional Nomor 1 Tahun 1999 Tentang Tata Cara Penanganan Sengketa Pertanahan (selanjutnya disebut Permen No. 1 Tahun 1999) Pasal 1 yaitu:

"Sengketa pertanahan adalah perbedaan pendapat mengenai;"

1) Keabsahan suatu hak;

2) Pemberian ha katas tanah;

Pendaftaran hak atas tanah termasuk peralihan dan penerbitan tanda buktu haknya, antara pihak-pihak yang berkepentingan dengan instansi dilingkungan Badan Pertanahan Nasional, sedangkan pihak-pihak yang berkepentingan adalah pihak-pihak yang merasa mempunyai hubungan hukum dengan bidang tanah tertentu atau pihak lain yang kepentingannya terpengaruh oleh status hokum tanah tersebut, maka sengketa pertanahan yang timbul dewasa ini, pada umumnya dapat diklasifikasikan dalam kelompok-kelompok sebagai berikut :

1) Sengketa pertanahan yang bersifat politis

Sengketa pertanahan yang bersifat politis biasanya ditandai dari hal-hal sebagai berikut:

a) Melibatkan masyarakat banyak

b) Menimbulkan keresahan dan kerawanan masyarakat.

c) Menimbulkan ketidakpercayaan kepada pemerintah /penyelenggara Negara.

d) Mengganggu penyelenggaraan pembangunan nasional, serta menimbulkan bahaya disintegrasi bangsa. ${ }^{18}$

Sengketa yang bersifat politis ini biasanya tidak didasarkan pada alasan-alasan hukum melainkan dengan memanfaatkan isu-isu politis sehingga terbentuk opini masyarakat yang mengarah pada ketidakpercayaan masyarakat kepada pemerintah. Keadaan seperti ini lebih lanjut akan melahirkan gangguan-gangguan social, politik, ekonomi maupun keamanan. Meskipun demikian, sngketa-sengketa yang tidak bersifat politis-pun apabila tidak ditangani secara adil dapat berkembang menjadi sengketa yang bersifat politis.

Sengketa yang bersifat politis tersebut antara lain disebabkan:

a) Eksploitasi dan dramatisasi ketimpangan-ketimpangan keadaan penguasaan dan pemilikan tanah didalam masyarakat, dan

b) Tuntunan keadilan dan keberpihakan pada golongan ekonomi lemah. ${ }^{19}$

Manifestasi dan bentuk sengketa yang bersifat politis diatas, dilakukan dalam bentuk unjuk rasa, penekanan-penekanan kepada institusi pemerintah dengan institusi yang dirasakan dapat menyalurkan aspirasi masyarakat seperti lembaga swadaya masyarakat, lembaga perwakilan rakyat, Komisi Nasional HAM, Komisi Ombudsman bahkan sampai ke lembaga Kepresidenan.

2) Bentuk-bentuk sengketa pertanahan yang bersifat strategis antara lain :

a) Tuntutan pengembalian tanah (reclaiming action) sebagai akibat pengembalian tanah pada jaman pemerintahan colonial.

b) Tuntutsn pengembalian tanah garapan yang kini dikuasai oleh pihak lain.

c) Penyerobotan tanah-tanah perkebunan.

d) Pendudukan tanak-tanah asset instansi pemerintah.

e) Tuntutan pemberian hak atas tanah bekas tanah partikelir yang diduduki rakyat

${ }^{16}$ Murad, Rusmadi. (2007). Menyingkap Tabir Masalah Pertanahan. Bandung: Mandar Maju, h. 77.

17 Kusmayanti, H., \& Hawari, S.Y. (2020). Praktik Eksekusi Riil Tanah Milik Masyarakat Adat Sunda Wiwitan. SASI, 26 (3), 341-355. https://doi.org/10.47268/sasi.v26i3.285, h. 350.

18 Ibid, h. 77.

19 Ibid, h. 78.

107 |S A S I Vo1. 27 No.1, Januari- Maret 2021 
f) Tuntutan pengembalian tanah atau tuntutan ganti rugi sebagai akibat kebijakan pembebasan tanah untuk pembangunan dimasa lalu.

g) Tuntutan penguasaan tanah oleh masyarakat hukum adat atas tanah ulayat diwilayahnya.

h) Tuntutan redistribusi tanah yang terkena obyek landreform.

i) Tuntutan atas proses perolehan hakatas tanah yang tidak mempertimbangkan ketersediaan tanah bagi masyarakat atau kepentingan masyarakat disekitarnya.

j) Tuntutan pengembalian tanah yang penggunaannya tidak sesuai denga ijin lokasi.

k) Masalah tanah milik organisasi terlarang, masalah tanah milik warganegara Belanda yang terkena ketentuan ndang-Undang Nornor 3 Tahun 1960

1) Masalah-masalah yang timbul sebagai akibat dan kegiatan pengadaantanah untuk pembangunan dalam sekala besar. ${ }^{20}$

\section{Penyelesaian Sengketa hak ulayat pada masyarakat}

Maka itu berdasarkan sifatnya yang sangat vital, sangketa tanah dapat menimbulkan gangguan-gangguan dan melibatkan masyarakat banyak maka dituntut penangan secara tepat. para pihak yang terkait dan berwenang menangani permasalahan tersebut menyelesaikan dengan berbagai cara. Cara penyelesaian sengketa yang telah ditempuh selama ini adalah melalui pengadilan (litigasi), dalam dimensi yuridis penguasaan tanah dan pemilikan tanah memerlukan perlindungan, implikasinya harus terdapat perlindungan hukum terhadap hak-hak keperdataan pemilikan tanah dan perlakuan yang adil terhadap kepemilikan tanah tersebut. Sengketa tanah yang berlarut-larut dan tidak ada penyelesaian yang baik dapat menyebabkan pihak yang dirugikan melakukan gugatan ke pengadilan. Meskipun ada peluang lebar menggugat melalui pengadilan tetapi pihak awam cenderung menghindarinya, selain itu terdapat anggapan dalam masyarakat bahwa pengajuan gugatan lewat pengadilan relatif mahal, memakan waktu yang cukup lama bahkan berbelit-belit. Oleh karena itu diupayakan masyarakat menyelesaikan sengketanya dengan menempuh jalur non litigasi. Penyelesaian melalui jalur pengadilan bertujuan untuk mendapatkan keadilan dan kepastian hukum, maka penyelesaian di luar pengadilan justru yang diutamakan adalah perdamaian dalam mengatasi sengketa yang terjadi di antara yang bersengketa dan bukan mencari pihak yang benar atau salah. $^{21}$

Bila harus mencari siapa yang benar dan yang salah tidak akan menghasilkan keputusan yang menguntungkan para pihak yang bersengketa. Penyelesaian sengketa non litigasi atau alternative yang lebih dikenal dengan istilah Alternatif Dispute Resolution (ADR) diatur dalam UndangUndang Nomor 9 tahun 1999 tentang Arbitrase dan Alternatif Penyelesaian Sengketa. Mekanisme penyelesaian sengketa dengan cara ini digolongkan dalam media non litigasi yaitu merupakan konsep penyelesaian konflik atau sengketa yang kooperatif yang diarahkan pada suatu kesepakatan satu solusi terhadap konflik atau sengketa yang bersifat win-win solution. ADR dikembangkan oleh para praktisi hukum dan akademisi sebagai cara penyelesaian sengketa yang lebih memiliki akses pada keadilan. Meskipun permasalahan pertanahan dan penyelesaian yang timbul dari permasalahan tersebut telah diatur sedemikian rupa, namun para pihak yang terlibat di dalamnya mempunyai cara sendiri-sendiri yang mereka anggap lebih baik atau lebih cocok dipakai untuk menyelesaikan permasalahan pertanahan yang dialami. Kehidupan masyarakat dan negara selalu berkembang sesuai denganperkembangan zaman. Bagi masyarakat perkembangan tersebut merupakan tuntutan perkembangan tersebut mencakup seluruh aspek kehidupan, termasuk yang berhubungan dengan pertanahan.

Tanah yang menjadi faktor yang sangat penting bagi masyarakat dan negara harus pula

20 Ibid, h. 79.

21 Usman, Rachamadi. (2003). Pilihan Penyelesaian Sengketa di Luar Pengadilan, Bandung: Citra Aditya Bakti, h. 4.

108 |S A S I Vol. 27 No.1, Januari- Maret 2021 
rnenyesuaikan dengan kebutuhan masyarakat serta kepentingan negara, dalarn rangka memenuhi tuntutan diperlukan persedian tanah untuk menampung dinamika perkembangan tersebut.

Sementara untuk rnenjamin terlaksananya fungsi tanah sebagai sarana pemenuhan kepentingan dan kebutuhan masyarakat dan negara, dituntut adanya kepastian hukurn hak atas tanah. Namun demikian tuntutan akan kepastian tersebut seringkali belum sesuai harapannya, hal ini tampak dari adanya sengketa pertanahan.

Upaya untuk mencari penyelesaian sengketa pertanahan, tidak dapat dilepaskan dan upaya untuk memahami berbagai akar permasalahan pertanahan yang sedemikian kompleks dimensinya. Akar permasalahan sengketa pertanahan dalam garis besarnya dapat ditimbulkan oleh hal-hal sebagai berikut: ${ }^{22}$

1) Konflik kepentingan, yang disebabkan karena adanya persaingan kepentingan yang terkait dengan kepentingan substantif (contoh: hak atas sumber daya agraria termasuk tanah), kepentingan prosedural maupun kepentingan psikologis.

2) Konflik struktural, yang disebabkan antara lainkarena : pola perilaku atauinteraksi yang destruktif; kontrol pemilikan atau pembagian sumber daya yangtidak seimbang; kekuasaan dan kewenangan yang tidak seimbang; serta factor geografis, fisik atau lingkungan yang rnenghambat kerjasama.

3) Konflik nilai, disebabkan karena perbedaan kriteria yang digunakan untukmengevaluasi gagasan atau perilaku; perbedaangaya hidup, ideologi atauAgama/kepercayaan.

4) Konflik hubungan, yang disebabkan karena ernosi yang berlebihan, persepsiyang keliru, kornunikasi yang buruk atau salah pengulangan perilaku yang negative.

5) Konflik data, yang disebabkan karena informasi yang tidak lengkap; informasiyang keliru; pendapat yang berbeda tentang hal-hal yang relevan; interpretasi data yang berbeda; dan perbedaan prosedur penilaian (Moore, 1996).

Pemahaman terhadap berbagai akar permasalahan tersebut dapat dijadikantitik tolak dalam upaya penyelesaian sengketa pertanahan yang timbul. Mekanisme penyelesaian sengketa yang pada umumnya ditempuh oleh Badan Pertanahan Nasional (BPN) adalah sebagai berikut:

a) Bila ditemukan cacat administratif karena kekeliruan data awal, maka koreksi administratif dilakukan oleh BPN.

b) Bila kedua belah pihak saling terbuka, diusahakan musyawarah yangdifasilitasi oleh BPN.

c) Bila sengketa melibatkan instansi sektoral, diupayakan koordinasi antarsektor.

d) Bila semua usaha telah menemui kegagalan, utamanya bila obyek sengketa berkenaan dengan masalah "hak" yang berkaitan dengan kebenaran material,maka upaya terakhir adalah melalui pengadilan. ${ }^{23}$

Berkenaan dengan mekanisme penyelesaian sengketa tersebut di atas terdapat berbagai hambatan yang perlu disampaikan sebagai catatan. Upaya penyelesaian berupa koreksi administratif oleh BPN pada umumnya dilakukan dalam bentuk pembatalan Surat Keputusan Pemberian Hak Atas Tanah atau sertifikat hak atas tanah, baik karena dijumpai adanya cacat hukum administrasi dalam penerbitan keputusan pemberian dan/atau sertifikat hakatas tanah karena melaksanakan putusan pengadilan. ${ }^{24}$

Sebagai instansi yang bertanggung jawab untuk urusan pelayananadministratif, BPN tidak berwenang untuk melakukan uji materiil dalarn rangkamenemukan kebenaran terhadap sengketa bcrkenaan dengan kebenaran data yuridis dan/atau data fisik, namun seringkali pihak

22 Sumardjono, Maria S. W. Op. Cit. h. 112.

23 Ibid, h. 113.

24 Ibid, h. 113.

109 |S A S I Vo1. 27 No.1, Januari- Maret 2021 
yang bersengketa kurang memahami perbedaan kewenangan BPN yang termasuk dalarn lingkup hukumadministrasi dan kewengan melakukan uji materiil yang merupakan kewenanganbadan peradilan.

Kurang pemahaman ini seringkali rnenyebabkan banyaknya kasus/sengketa yang masuk ke BPN dan setelah diteliti ternyata penyelesaiannya tidak rnenjadi wewenang BPN atau tindakan yang diharapkan dan BPN tidak dapat serta merta dilakukan karena misalnya, telah ditangani oleh pengadilan dan belum rnempunyai kekuatan hukum yang tetap. ${ }^{25}$

Berkenaan dengan sengketa yang terkait dengan masalah pendudukan dan penggarapan tanah dan sumber daya agraria selain tanah, terdapat 2 (dua) pola dasar pada pelakunya, yakni dilakukan oleh mereka yang merasa merniliki hak atas tanah atau sumber daya agraris selain tanah dan pendudukan/pcnggarapan sumber daya agraria yang tidak produktif atau dianggap tidak produktif oleh kelompok masyarakat yang tinggal di sekilar lokasi tanpa memperdulikan alas hak melainkan karena tidak tercapainya rasa keadilan yang subyektif. ${ }^{26}$

Hal ini memberikan gambaran bahwa seringkali tidak mudah untuk membedakan antara tuntutan yang didasarkan pada alas hak atau tuntutan yang tidak berdasarkan alas hak, dan keadaan itu dengan rnudah dapat dirnanfaatkan oleh pihak ketiga yang tidak beritikad baik. Dalam hal penyelesaian upaya sengketa memerlukan koordinasi antarinstansi, rnisalnya dalarn sengketa antar masyarakat dengan melibatkan instansi kehutanan, ABRI, Departernen Perhubungan, dan lain-lain, koordinasi yang diharapkan tidak selalu dapat dilaksanakan. Salah satu alasan sulitnya melaksanakan koordinasi antar instansi, terutama instansi sektoral, adalah karena dari segi nominatif peraturan perundang-undangan sektoral yang sentralislik itu sering tumpang tindih dan tidak konsisten satu sarna lain. ${ }^{27}$

Dari segi empiris, tidak adanya satu instansi yang bertanggung jawabuntuk rnengkoordinasikan kebijakan dan pelaksanaan kebijakan antar sector mendorong setiap sektor untuk bertindak dalam ruang vertikal masing-rnasing dengan menyisakan sedikit kesempatan untuk melakukan koordinasi horizontal, dalarn hal diperlukannya koordinasi antar instansi, dengan tujuan untukmemberikan keadilan dan kepastian hukum bagi masyarakat terhadap hak atas tanahnya, diperlukan peran Dewan Perwakilan Rakyat dalam rangka rnelaksanakan fungsi pengawasan untuk memfasilitasi pertemuan dengan instansi terkait untuk rnelakukan koordinasi yang diperlukan.

Seiring dengan perjalanan waktu, penyelesaian sengketa melalui cara musyawarah semakin bayak di lakukan. Sengketa pertanahan yang lebih banyak berkaitan dengan rnasalah kepentingan atau interes para pihak, relatif lebih mudah untuk diselesaikan melalui cara musyawarah sepanjang kedua belah pihak saling terbuka dan menginginkan jalan keluar yang terbaik bagi semua pihak.

Temuan hasil penelitian berkenaan dengan Potensi Penerapan Penyelesaian Sengketa Alternatif (ADR) di Bidang Pertanahan mengungkapkan hal-hal sebagai berikut:

1) Berbagai kasus pertanahan yang bersifat horizontal maupun vertikal, baikyang melibatkan sengketa antarwarga masyarakat, antara warga masyarakat dengan badan usaha atau instansi pemerintah, terbuka kemungkinannya untukdiselesaikan dengan cara perundingan atau mediasi.

2) Persepsi warga masyarakat terhadap cara penyelesaian sengketa di luar pengadilan yang mereka gunakan bervariasi. Ada yang berpandangan bahwapihak yang diminta menyelesaikan, dalam hal ini fasilitator; hanya berperansebagai tempat mengadu berkenaan dengan konflik pertanahan yang dihadapi, sementara salah satu pihak berada dalarn posisi yang lemah berhadapandengan lawan konflik. Narnun, pada

25 Ibid, h. 114.

26 Naskah Akademis. (2004). Gagasan Pembentukan Komite Nasional untuk Penyelesaian Konflik Agraria.

${ }^{27}$ Ibid, h. 113.

110 | S A S I Vo1. 27 No.1, Januari- Maret 2021 
akhirnya pihak yang diminta menjadi fasilitator atau mediator tersebut diharapkan ikut memperjuangkan kepentingannya.

Sebagian masyarakat lainnya memandang penyelesaian sengketa diluar pengadilan sebagai cara untuk rnemenangkan konflik, baik karena mereka mempunyai dasar untuk memenangkannya maupun tidak. Untuk itu, di tengah terjadinya proses penyelesaian, mereka mengerahkan dukungan dari warga masyarakat lainnya untuk menunjukkan kekuatannya rnelalui unjuk rasa, demonstrasi, dan cara lain untuk memengaruhi proses penyelesaian sengketa sehingga dapat mengabulkan tuntutan mereka, terdapat juga warga masyarakat yang dengan penuh kesadaran menempatkancara penyelesaian di luar pengadilan sebagaimana mestinya. Apabilakesempatan tercapai, maka hasilnya tidak menimbulkan konflik berkelanjutan. Artinya kedua belah pihak merasa tidak direndahkan dan dipermalukandengan adanya kesepakatan bersama itu.

Hasil kesepakatan atau keputusan tidak selamanya dipatuhi dan dilaksanakan oleh para pihak. Hal ini menunjukkan norma moral sebagai dasar untuk melaksanakan hasil kesepakatan atau keputusan itu belum dihayati oleh warga masyarakat yang menempuh cara penyelesaian sengketa di luar pengadilan. ${ }^{28}$

\section{PE N U T U P}

Sengketa tanah yang berlarut-larut dan tidak ada penyelesaian yang baik dapat menyebabkan pihakmyang dirugikan melakukan gugatan ke pengadilan. Meskipun ada peluang lebar menggugat melalui pengadilan tetapi pihak awam cenderung menghindarinya, selain itu terdapat anggapan dalam masyarakat bahwa pengajuan gugatan lewat pengadilan relatif mahal, memakan waktu yang cukup lama bahkan berbelit-belit. Oleh karena itu diupayakan masyarakat menyelesaikan sengketanya dengan menempuh jalur non litigasi. Penyelesaian melalui jalur pengadilan bertujuan untuk mendapatkan keadilan dan kepastian hukum, maka penyelesaian di luar pengadilan justru yang diutamakan adalah perdamaian dalam mengatasi sengketa yang terjadi di antara yang bersengketa dan bukan mencari pihak yang benar atau salah. Bila harus mencari siapa yang benar dan yang salah tidak akan menghasilkan keputusan yang menguntungkan para pihak yang bersengketa

\section{DAFTAR PUSTAKA}

\section{Jurnal}

[1] Achmad, I. A., Risdiwanto, G., \& Rezandy, J. G. (2020). Kewenangan Hak Menguasai Negara Atas Hak Ulayat Pada Kawasan Hutan Lindung. Soumatera Law Review, 3 (1), 81 92. http://doi.org/10.22216/soumlaw.v3i1.5102.

[2] Hetharie, Y. (2019). Perjanjian Nominee sebagai Sarana Penguasaan Hak Milik atas Tanah oleh Warga Negara Asing (WNA) Menurut Kitab Undang-Undang Hukum Perdata. SASI, 25(1), 27-36. DOI: https://doi.org/10.47268/sasi.v25i1.147.

[3] Hallauw, D. K., Matuankotta, J. K., \& Uktolseja, N. (2020). Analisis Hukum Surat Pelepasan Hak Atas Tanah Adat (Dati) Di Kota Ambon. SASI, 26 (1), 111118. https://doi.org/10.47268/sasi.v26i1.256.

[4] Kotalewala, F., Laturette, A.I., \& Uktolseja, N. (2020). Penyelesaian Sengketa dalam Pengadaan Tanah Bagi Pembangunan Jalan untuk Kepentingan Umum. SASI, 26 (3), $415-$ 433. https://doi.org/10.47268/sasi.v26i3.397.

[5] Kusmayanti, H., \& Hawari, S.Y. (2020). Praktik Eksekusi Riil Tanah Milik Masyarakat Adat Sunda Wiwitan. SASI, 26 (3), 341-355. https://doi.org/10.47268/sasi.v26i3.285.

[6] Laturette, A. I. (2016). Penyelesaian Sengketa Hak Atas Tanah Masyarakat Hukum

${ }^{28}$ Sumardjono, Maria S. W. Op. Cit, h. 115.

111 |S ASI Vo1. 27 No.1, Januari - Maret 2021 
Adat. SASI, 22(2), 52-66. DOI: https://doi.org/10.47268/sasi.v22i2.168.

[7] Lakburlawal, M. A. (2016). Akses Keadilan bagi Masyarakat Adat dalam Penyelesaian Sengketa Tanah Ulayat yang Diberikan Hak Guna Usaha. ADHAPER: Jurnal Hukum Acara Perdata, 2 (1), 59-75. http://doi.org/10.36913/jhaper.v2i1.24.

[8] Riardo, Rahmat. (2019). Konversi Hak Atas Tanah Ulayat Kaum Menjadi Hak Milik Melalui Program Pendaftaran Tanah Sistimatis Lengkap di Kota Solok. Soumatera Law Review, 2 (2), 193-206. http://doi.org/10.22216/soumlaw.v2i2.3556.

[9] Shidarta. (2010). Peragaan Pola Penalaran Hukum dalam Kajian Putusan Kasus Tanah Adat”. Jurnal Yudisial, 3 (3), 207-219. http://dx.doi.org/10.29123/jy.v3i3.208.

[10] Saija, R., Letsoin, F.X., Akyuwen, R.J., \& Radjawane, P. (2020). Status Kepemilikan Hak Atas Tanah Adat Marga dalam Kebijakan Penataan Aset Reforma Agraria Di Kabupaten Maluku Tenggara. SASI, 26 (1), 99-110. https://doi.org/10.47268/sasi.v26i1.246.

[11] Warman, Kurnia. \& Syofiarti. (2012). Pola Penyelesaian Sengketa Tanah Ulayat Di Sumatera Barat (Sengketa antara Masyarakat vs Pemerintah). Masalah-Masalah Hukum, 41 (3), 407-415. https://ejournal.undip.ac.id/index.php/mmh/article/view/5771.

\section{Buku}

[12] Irianto, Sulistyowati. (2009). Praktik Hukum: Perspektif Sosiolegal, Jakarta: Yayasan Obor.

[13] Murad, Rusmadi. (2007). Menyingkap Tabir Masalah Pertanahan. Bandung: Mandar Maju.

[14] Sumardjono, Maria S.W. (2005). Kebijakan Pertanahan, Antara Regulasi dan Implementasi, Jakarta: Kompas.

[15] Usman, Rachamadi. (2003). Pilihan Penyelesaian Sengketa di Luar Pengadilan, Bandung: Citra Aditya Bakti.

\section{Lain-Lain}

[16] Naskah Akademis. (2004). Gagasan Pembentukan Komite Nasional untuk Penyelesaian Konflik Agraria. 